Research Article

\title{
Effect of Artesunate on Peripheral Parasitaemia in Pregnant Women with Plasmodium Falciparum Infection
}

\section{Efek Artesunat pada Perempuan Hamil dengan Infeksi Plasmodium Falciparum terhadap Kejadian Parasitemia Perifer}

\author{
Susi W Saragih'1, St. Maisuri T. Chalid' ${ }^{1}$, Umar Malinta1, Isra Wahid ${ }^{2}$ \\ ${ }^{1}$ Department of Obstetrics and Gynecology \\ ${ }^{2}$ Department of Parasitology \\ Faculty of Medicine Universitas Hasanuddin/ \\ Makassar
}

\begin{abstract}
Objective: To determine the effect of artesunate on peripheral parasitaemia in pregnant women with Plasmodium falciparum infection.

Methods: Pregnant women in second and third trimester with Plasmodium falciparum infection and their newborns were included in cohort prospective study in Sorong West Papua from September 2015 to February 2016. All pregnant women received $200 \mathrm{mg}$ orally artesunate monotherapy for 7 days. Their newborns examined for weight at delivery and parasitaemia in placenta and cord blood. Parasitaemia diagnosis by Rapid Diagnostic Test and blood smear microscopy.
\end{abstract}

Results: After artesunatemonotherapy, 82.5\% (33/40) malariainfected pregnant women had negative parasitaemia $(\mathrm{p}=0.000)$ although $17.5 \%(7 / 40)$ of the pregnant women had positive parasitaemia. Parasitaemia also found in $10 \%(4 / 40)$ of placenta and $7.5 \%(3 / 40)$ of umbilical cord from newborns of malaria-infected pregnant women treated with artesunate. $70 \%(28 / 40)$ of the newborns in this study had normal weight.

Conclusion: Artesunate reduces peripheral parasitaemia in the second and third trimester of pregnancy, and is associated with normal birth weight.

[Indones J Obstet Gynecol 2017; 5-3: 135-138]

Keywords: artesunate, low birth weight, peripheral parasitaemia

\begin{abstract}
Abstrak
Tujuan: Untuk mengetahui pengaruh artesunat pada ibu hamil yang terinfeksi Plasmodium falciparum dengan kejadian parasitemia perifer.

Metode: Penelitian kohort prospektif dilakukan pada perempuan hamil trimester kedua dan ketiga dengan infeksi Plasmodium falciparum dan bayinya di Sorong Papua Barat dari September 2015 sampai Februari 2016. Semua perempuan hamil memperoleh mono terapi artesunat $200 \mathrm{mg}$ per oral selama 7 hari. Pada bayi dilakukan pemeriksaan berat badan saat persalinan dan parasitemia pada plasenta dan darah tali pusat. Diagnosis parasitemia dengan Rapid Diagnostic Test dan pemeriksaan apusan darah mikroskopik.

Hasil: Setelah terapi artesunat, ditemukan parasitemia negatif pada $82,5 \%$ (33/40) perempuan hamil yang terinfeksi malaria ( $p=$ 0,000) meskipun 17,5\% (7/40) di antaranya parasitemia positif Parasitemia juga ditemukan 10\% (4/40) pada plasenta dan 7,5\% (3/40) pada tali pusat bayi yang lahir dari perempuan dengan infeksi Plasmodium falciparum yang mendapatkan pengobatan artesunat. 70\% (28/40) dari bayi yang lahir dalam penelitian memiliki berat badan normal.

Kesimpulan: Artesunat menurunkan kejadian parasitemia perifer pada perempuan hamil trimester kedua dan ketiga. Bayi yang lahir dari perempuan hamil yang mendapatkan terapi artesunat memiliki berat badan normal.

[Maj Obstet Ginekol Indones 2017; 5-3: 135-138]

Kata kunci: artesunat, berat bayi lahir rendah, parasitemia perifer
\end{abstract}

\section{INTRODUCTION}

Pregnant women are vulnerable to malaria infection. Pregnancy-associated malaria can causes adverse pregnancy outcomes including abortion, preterm birth, low birth weight, congenital malaria, intrauterine growth retardation (IUGR), anemia and metabolic disorders that increase the risk of disease in later stages of child development. ${ }^{1}$
Numerous studies have reported on the prevalence of peripheral parasitaemia and placental parasitaemia in the area stable endemic malaria transmission in Africa. The median prevalence of maternal malaria infection (defined as an infection of peripheral or placenta) for all gravid was $27.8 \%$. The highest risk of maternal malaria infection occurred during the second trimester of pregnancy while at the early postpartum period study showed inconsistent. $^{2}$ 
Plasmodium falciparum is the most common Plasmodium species in Indonesia. ${ }^{3}$ A study in Timika- Papua, an area of multidrug-resistant to P. vivax and $P$. falciparum, show both species are associated with substantial morbidity. ${ }^{4} \mathrm{P}$. vivax and $P$. falciparum have been previously reported to be chloroquine resistant in Papua. ${ }^{5}$

Any attempt for malaria prevention in Indonesia is controlled by Annual Parasite Incidence (API) since 2007. This policy requires that every case of malaria infection has to be confirmed with blood smear microscopy and treated with artemisinbased combination therapy (ACT). ${ }^{6}$ ACT significantly reduced the vertical transmission risk of malaria in Papua. ${ }^{7}$ Other studies demonstrated that a single dose of artesunate monotherapy was effective and had no adverse effect in the second and third trimester of pregnancy. ${ }^{8}$

This study is aimed to determine the effect of artesunate therapy in peripheral parasitaemia on second and third trimester of pregnancy with P. falciparum infection and their newborns after treatment.

\section{METHODS}

This prospective cohort study was conducted in health facilities in Sorong, West Papua from September 2015 to February 2016. Pregnant women infected with falciparum malaria in the second and third trimester and their newborns from Waisai General Hospital, Timika General Hospital, Sele Be Solu Hospital and Makbon Community Health Center were enrolled in this study. Parasitaemia in capillary blood from pregnant women and placenta and cord blood from newborns were diagnosed by blood smear microscopy and a Rapid Diagnostic Test (RDT). Pregnant women were administered with artesunate monotherapy 200 $\mathrm{mg}(4 \mathrm{mg} / \mathrm{kg}$ ) per oral once daily for 7 days. Newborns weight was measured at delivery; birth weight $<2500 \mathrm{~g}$ defined as low birth weight. Pregnant women with complicated malaria, have taken other anti-malarial drugs prior to data collection, and unwilling to join the study were excluded. McNemar test was used to analyze the effect of artesunate therapy on peripheral parasitaemia. The study protocol was approved by the Health Research Ethics Committee of Faculty of Medicine, Hasanuddin University.

\section{RESULTS}

This study involved 40 pregnant women with falciparum malaria. After being administered with artesunate therapy, $82.5 \%$ (33/40) malariainfected pregnant women had negative parasitaemia although $17.5 \%$ (7/40) of these women had positive parasitaemia $(17.5 \%)$. These differences were statistically significant $(\mathrm{p}<0.001)$. The results are shown in Table 1.

Table 1. Peripheral Parasitaemia on Pregnant Women after Treated with Artesunate

\begin{tabular}{lccc}
\hline \hline $\begin{array}{c}\text { Parasitaemia } \\
(\mathbf{n = 4 0 )}\end{array}$ & $\begin{array}{c}\text { Negative } \\
\mathbf{n}(\%)\end{array}$ & $\begin{array}{c}\text { Positive } \\
\mathbf{n}(\%)\end{array}$ & $\mathbf{p}^{*}$ \\
\hline RDT & $33(82.5)$ & $7(17.5)$ & $<0.001$ \\
Microscopic & $33(82.5)$ & $7(17.5)$ & $<0.001$ \\
\hline \hline *McNemar test & & &
\end{tabular}

Parasitaemia positive was found $10 \%(4 / 40)$ positive in placenta and $7.5 \%(3 / 40)$ in umbilical cord from newborns of malaria-infected women treated with artesunate (Table 2). Seventy percent of the newborns in this study born had normal birthweight (Table 3).

Table 2. Parasitaemia on Placenta and Umbilical Cord

\begin{tabular}{lcc}
\hline \hline Parasitaemia (n=40) & Negative n\% & Positive $\mathbf{n} \%$ \\
\hline Placenta & $36(90)$ & $4(10)$ \\
RDT & $36(90)$ & $4(10)$ \\
Microscopic & & \\
Umbilical cord & $37(92.5)$ & $3(7.5)$ \\
RDT & $37(92.5)$ & $3(7.5)$ \\
Microscopic &
\end{tabular}

Table 3. Pregnancy Outcomes after Being Administered with ArtesunateMonotherapy

\begin{tabular}{ll}
\hline \hline Low birth weight & n (\%) \\
\hline Yes & $12(30)$ \\
No & $28(70)$ \\
\hline \hline
\end{tabular}

\section{DISCUSSION}

The study is aimed to determine the effect of artesunate therapy in peripheral parasitaemia on 
second and third trimester of pregnancy with $P$. falciparum infection. Artesunate therapy in this study reduced peripheral parasitaemia in pregnant women. A single dose of oral artesunate is effective and have no adverse effects on the second and third trimester of pregnancy. ${ }^{8} \mathrm{~A}$ previous study has found that anti-malaria artesunate monotherapy in the second and third trimester of pregnancy has a better efficacy compared to 6 doses of artemetherlumefantrine. ${ }^{9}$ Artesunate may also delay the onset of hemolysis in severe malaria. ${ }^{10}$

Artesunate is sodium salt of the hemisuccinate ester of artemisinin. It is soluble in water but has poor stability in aqueous solutions at neutral or acid $\mathrm{pH}$. It is rapidly absorbed with peak plasma levels occuring after 1.5 hours for oral, rectal and 2 hours to 0.5 hours for injections. ${ }^{11}$ Artemisin and its derivatives (artesunate, artemether, dihydroartemisinin) are rapidly hydrolyzed in vivo into the activity dihidroartemisin with equivalent antimalaria. ${ }^{12}$ Four possible mechanisms of artemisin action against plasmodia when artemisin activated through disconnection intrinsic bond peroxide are line error detoxify heme groups, the induction of the alkylation process translational control of protein tumor (PfTCTP) and other proteins, inhibition of PfATPase6 enzyme activity and interference the function of Plasmodium mitochondria. ${ }^{13}$

In this study, we found that the parasites remained in peripheral blood after being administered with artesunate therapy in pregnant women and in the placenta as well as umbilical cord of newborns through RDT and microscopic examination. The prevalence of parasitaemia varied. This might be a result of differences in the definition of congenital malaria, maternal immunity level, types of blood samples examined (peripheral blood or cord blood of neonates), the expertise in microscopic examination, the parasite detection methods (microscopic or PCR) and differences in geographical factors of malaria-endemic areas. ${ }^{14}$ The prevalence of malarial parasite is different with different examination methods. A previous study indicated that the prevalence of malarial infection in the placenta with RDT, microscopy and PCR was 95\%, $70 \%$ and $100 \%$ while in the umbilical cord was $10 \%, 12.8 \%$ and $95 \%$, respectively. ${ }^{15}$ Fetal exposure to malarial parasites in utero has been proposed to modify the immune response of newborns, increasing their susceptibility to symptomatic malaria infections at birth and later in life. ${ }^{16-18}$
Low birth weight is one of the adverse outcomes in pregnancy-associated malaria in all levels of endemicity. Pregnant women with falciparum and vivax malaria are at higher risk for low birth weight. Low birth weight is associated with the mechanical obstruction of malaria parasite that attached to chondroitin sulphate A (CSA) receptors in the syncytiotrophoblast of the placenta that impaired circulation from mother to fetus and affect the transport of oxygen and nutrients. But research by Pongtasik conducted in malaria endemic areas of East Nusa Tenggara expression CSA in pregnant women with placental malaria had no correlation with malaria infection of peripheral blood postpartum. ${ }^{19}$

Primigravida has been associated with increased risk of malarial infection. In areas where $P$. falciparum is endemic, parity reduced vulnerability to malaria infection during pregnancy. This is due to lack of antibodies that can blocked adhesion of erythrocytes-malaria infected to the placenta $\mathrm{CSA}^{20}$ CSA adhesion phenotype specific to placental parasites by the var gene expression (var2 csa). ${ }^{21}$ However, recent study suggested that CSA expression in the placenta not associated with parity and low birth weight. ${ }^{22}$

The majority of the newborns whose mothers were administered with artesunate during pregnancy had normal weight. The risk of low birth weight increased 2-fold in the area of stable transmission if the mother suffered from placental malaria with the largest effect on primigravidae. Odds ratio (OR) of low birth weight 2-7 times higher in primigravidae compared to multigravidae. ${ }^{1}$ The median reduction in birthweight in the reviewed studies was $150 \mathrm{~g}$ for P. falciparum or mixed infections and $108 \mathrm{~g}$ for P. vivax malaria. Malaria reduces birthweight occurs mainly in first pregnancies with P. falciparum but also in subsequent pregnancies, and even with one episode of P. vivax or P. falciparum. Both symptomatic and asymptomatic malaria episodes increase the risk of low birth weight, although symptomatic infections in pregnancy might have a larger effect than asymptomatic disease, particularly on premature delivery. ${ }^{23}$

\section{CONCLUSION}

In brief, we found artesunate monotherapy could reduce peripheral parasitaemia in the second and third trimester of pregnancy in pregnant women 
with malarial infection. Newborns whose mothers were received artesunate monotherapy had normal weight.

\section{REFERENCES}

1. Rogerson SJ, Hviid L, Duffy PE, et al. Malaria in pregnancy: Pathogenesis and immunity. Lancet Infect Dis 2007; 7: 10517.

2. Desai M, TerKuile FO, Nosten F, et al. Epidemiology and burden of malaria in pregnancy. Lancet Infect Dis 2007; 7(2): 93-104.

3. Elyazar IRF, Hay SI and Baird JK. Malaria distribution, prevalence, drug resistance and control in Indonesia. Adv Parasitol 2011; 74: 41-175.

4. Karyana M, Burdarm L, Yeung S, et al. Malaria morbidity in Papua Indonesia, an area with multidrug resistant Plasmodium vivax and Plasmodium falciparum. Malar J 2008; 7: 148.

5. Baird JK, Wiady I, Fryauff DJ, et al. In vivo resistance to chloroquine by Plasmodium vivax and Plasmodium falciparum at Nabire, Irian Jaya, Indonesia. Am J Trop Med Hyg 1997; 56(6): 627-31.

6. Direktorat Pengendalian Penyakit Bersumber Binatang. 2011. Epidemiologi malaria di Indonesia. Buletin Malaria, 2011; 1(1): 1-16.

7. Poespoprodjo JR, Fobia W, Kenangalem E, et al. Highly effective therapy for maternal malaria associated with a lower risk of vertical transmission. J Infect Dis 2011; 204: 1613-9.

8. Onyamboko MA, Meshnick SR, Lawrence Fleckenstein L, et al. Pharmacokinetics and pharmacodynamics of artesunate and dihydroartemisinin following oral treatment in pregnant women with asymptomatic Plasmodium falciparum infections in Kinshasa DRC. Malar J 2011; 10: 49.

9. McGready R, Tan SO, Ashley EA, et al. A randomised controlled trial of artemether-lumefantrine versus artesunate for uncomplicated Plasmodium falciparum treatment in pregnancy. PLoS Med 2008; 5(12): e253.

10. Rolling T, Wichmann D, Stefan Schmiedel S, et al. Artesunate versus quinine in the treatment of severe imported malaria: comparative analysis of adverse events focussing on delayed haemolysis. Malar J 2011; 12: 241.
11. WHO. Guidelines for the treatment of malaria. Second edition. 2010: 97.

12. Ward SA, Sevene EJP, Hastings IM, et al. Antimalarial drugs and pregnancy: safety, pharmacokinetics, and pharmacovigilance. Lancet Infect Dis 2007; 7: 136-44.

13. Ding XC, Beck HP, Raso G. 2011. Plasmodium sensitivity to artemisinins: magic bullets hit elusive targets. Trends Parasitol, 2011; 27(2): 73-81.

14. Uneke CJ. Impact of placental Plasmodium falciparum malaria on pregnancy and perinatal outcome in Sub-Saharan Africa. Yale J Biol Med. 2007; 81(1): 1-7.

15. Rambu W, Chalid SMT, Lukas E, Wahid I. The role of placental malaria and maternal conditions on the incidence of congenital malaria. Thesis. Post Graduate Program Hasanuddin University Makassar. 2015.

16. Broen K, Brustoski K, Engelmann I, Luty AJ. Placental Plasmodium falciparum infection: causes and consequences of in utero sensitization to parasite antigens. Mol BiochemParasitol 2007; 151: 1-8.

17. Dent A, Malhotra I, MungaiP, et al. Prenatal malaria immune experience affects acquisition of Plasmodium falciparum merozoite surfaceprotein-1 invasion inhibitory antibodies during infancy. J Immunol 2006; 177: 7139-45.

18. Malhotra I, Dent A, Mungai $P$, et al. Can prenatal malaria exposure produce an immune tolerant phenotype? A prospective birth cohort study in Kenya. PLoS Med 2009; 6: e1000116

19. Pongtasik N, Chalid SMT, Tahir M, et al. Correlation of Chondroitin sulfate A expression and placental malaria infection in peripheral blood postpartum. Thesis. Post Graduate Program Hasanuddin University Makassar. 2015.

20. Fried M, Meuhlenbachs A, Duffy PE. 2012. Diagnosing malaria in pregnancy: an update. Expert Rev Anti Infect Ther. 2012; 10(10): 1177-87.

21. Fried M, Duffy PE. Adherence of Plasmodium falciparum to chondroitin sulfate A in the human placenta. Science 1996; 272: 1502-04.

22. Taufik ES, Chalid SMT, Tessy T. Expression of chondroitin sulfate A in parity and low birth weight in pregnant women with malaria. Thesis. Post Graduate Program Hasanuddin University Makassar. 2015.

23. Rijken MJ, McGready R, Boel ME, et al. Malaria in pregnancy in the Asia-Pacific region. Lancet Infect Dis 2012; 12: 75-88. 